\title{
Innovation Strategy and Business Model For Batik SMEs In East Java Indonesia
}

\author{
Sri Wahyu Lelly Hana Setyanti \\ Faculty of Economics and Business \\ Universitas Jember, Indonesia \\ Lelyhana.fe@unej.ac.id
}

\begin{abstract}
In recent years, Small and Medium Enterprise (SME) in Batik industry has significant contribution for the development Indonesian economy. Innovation strategy and business model are the biggest challenges for the SME to increase its business growth. The objective of this research was to analyze the effect of innovation strategy on business model for Batik SMEs in East Java Province, Indonesia. A total of 80 SMEs was selected as the sample. This research employed in depth interview and quantitative method.
\end{abstract}

Keywords - batik, small medium enterprises, innovation strategy, and business model

\section{INTRODUCTION}

Recently, the SMEs in Batik industry are facing challenges and opportunities in terms of the increased total transaction of Batik products. In 2006, the transaction rate of Batik products was $56 \%$ or 2.9 trillion, which then increased to 3.9 trillion in 2015 . The growth rate of SMEs Batik in Indonesia had increased from 53,250 business units in 2009 employing 873,510 workers to 55,778 business units in 2015 employing 916,783 workers. But, on the other hand, the condition of increasingly competitive global market led to the decreasing export quantity of Indonesian Batik products since 2009.

For SMEs, innovation strategy is an effort to maintain the market share. Innovation strategy is defined as the process of adopting a new technology into a product with the purpose of giving an added value [1]. Innovation strategies can be applied on goods, services, or ideas received by an individual as a novelty. Even though the ideas might have emerged in the past, it could still be considered innovative if the consumers think about it as an innovation. Furthermore, as the business entity, SMEs with its flexible characteristics have to optimize their innovation strategy and turn it into strength and intangible resources to be managed professionally. Entrepreneur or anyone involved in the development of SMEs is expected to have an innovative behavior and high creativity to continuously create and develop a new innovation strategy for the competitive advantage. This superior quality culture is implemented into an innovation strategy that is internalized into the entire parts of the organization [2]. The importance of innovation strategy for the SMEs could be seen in the invention of new, better or more effective ways, compared to the previous ones, in producing products, services, and solutions. Innovation strategy is also very important for the endurance of any kind of business, whether it is in the creative sector, fashion industry, manufacture, or natural resources and so forth.

The importance of innovation strategy for the SMEs could be seen in the invention of new, better or more effective ways, compared to the previous ones, in producing products, services, and solutions. Innovation strategy is also very important for the endurance of any kind of business, whether it is in the creative sector, fashion industry, manufacture, or natural resources and so forth. To be able to survive in a competitive business, each business unit must constantly strive to discover new ideas, to build creativity so that new innovation strategies could be created. Without innovation, the organization will become obsolete, fragile, and cannot survive in a long period of time. But, innovation is not always associated merely with the sophisticated new things, because what's more important is how the company is able to provide added value to the produced products and services. Therefore, innovation strategies should be developed through innovative culture, continuous improvement or transformation, and responsiveness to market changes [3].

In the global economy and free trade era, the business competition is increasingly fierce. Business model as a method used by the company to run its business, which helps the company to survive. In short, according to this definition, the business model is a method or means, namely the way to create value [4]. The components of a business model are the customer (target market/scope), value propositions, capabilities, cost, pricing, and revenue sources [5]. Tight competition has also occured in Batik SMEs industry in Indonesia. In recent years, Batik pattern textile from some countries such as Malaysia, Thailand, Singapore, South Africa, and Poland were flooded in Indonesian market and threatened the existence of traditional Batik SMEs as the producers of handmade and printed Batiks. This phenomenon happened due to the advanced technology invention that led to mass and quick production of Batik pattern textile with a relatively cheaper price. Of course, it attracted more consumers, particularly for the lower middle class segment.

Many newly launched Batik SMEs' products failed in the marketplace because of the lack of market research in analyzing the needs and wants of the consumers. Batik SMEs could perform simple market research by identifying what 
consumers need, how they respond to the product and its attributes (e.g., price, packaging, size), the management of product delivery, and most importantly the changes in consumers' tastes. Some SMEs often implemented a small scale production as the market testing to evaluate the response of the consumers. They also distributed free sample or tester to the market to promote the new product. This kind of innovation strategy is an attempt to provide products with the different functionality, packaging, and qualities followed by continuous improvement in order to create a competitive advantage in a constantly changing market.

\section{METHOD OF RESEARCH}

This study used two kinds of analysis, namely descriptive analysis and inferential statistical analysis or quantitative techniques referring to the field data [6]. Descriptive analysis was used to describe in an in depth analysis to each variable of the study. While quantitative techniques were used to analyze the strength of the effect of independent variables on dependent variables.

\section{RESULT AND DISCUSSION}

Respondents of this study were consisted of men $(51 \%)$ and women $(49 \%)$. The majority of respondents $(51 \%)$ was at the age of more than 45 years old. Based on business experience, most respondents $(61 \%)$ had more that 20 years experience in running the business. Most produced products were handmade Batik (71\%). Most respondents (44\%) employed about 11-20 workers in their enterprises. From the level of education, the majority of respondents $(61 \%)$ were the senior high school graduates. Referring to the results of annual sales, most respondents (65\%) produced less than 500 pieces of Batik.

A summary of means and standard deviations for the independent and dependent variables of this study is shown in Table 1. Results showed that among three dimensions of innovation strategy, product innovation had the highest mean (4.0721), followed by process innovation (3.80220), and managerial innovation (3.7933). However, the mean score of the dependent variable (namely business model) was 3.7562 .

Table 1. Descriptive Statistics for the Main Variables of the Study

\begin{tabular}{ccc}
\hline Variable & Mean & Standard Deviation \\
\hline Product Innovation & 4.0721 & 0.54989 \\
\hline Process Innovation & 3.8022 & 0.52661 \\
\hline Managerial Innovation & 3.7933 & 0.53848 \\
\hline Business Model & 3.7562 & 0.53436 \\
\hline
\end{tabular}

Table 2. Results of Reliability Analysis

\begin{tabular}{cccc}
\hline Instrument & $\begin{array}{c}\text { Number of } \\
\text { Item }\end{array}$ & $\begin{array}{c}\text { Cronbach's } \\
\text { Alpha }\end{array}$ & $\begin{array}{c}\text { Cronbach's Alpha } \\
\text { Based on } \\
\text { Standardized Item }\end{array}$ \\
\hline Product Innovation & 6 & 0.849 & 0.852 \\
\hline Process Innovation & 6 & 0.836 & 0.838 \\
\hline $\begin{array}{c}\text { Managerial } \\
\text { Innovation }\end{array}$ & 6 & 0.828 & 0.831 \\
\hline Business Model & 4 & 0.824 & 0.828 \\
\hline
\end{tabular}

Results of reliability testing in this study are presented in Table 2. All constructs used in this study have achieved the acceptable level of reliability [7]. Correlation analysis was performed to determine if there was any correlation between the innovation strategy dimensions (namely: product innovation, process innovation and managerial innovation) and the dependent variable of this study (business model).

The main objective of this study was to analyze the effect of innovation strategy which consists of product innovation, process innovation, and managerial innovation on the business model of Batik SMEs in East Java Province, Indonesia. Three hypotheses were proposed in this study. First hypothesis proposed explanation about the effect of product innovation on business model. Second hypothesis proposed explanation about the effect of process innovation on business model, and third hypothesis proposed explanation about the effect of managerial innovation on business model of Batik SMEs in East Java Province. The results of simultaneous test explaining the effect of the three dimensions of innovation strategy on business model was 0.765 . The research findings also explained that the dimension of product innovation had a dominant effect on the increased business model of Batik SMEs.

Table 3. Multiple Regression Analysis of Innovation Strategy Dimensions and Business Model

\begin{tabular}{cccc}
\hline Independent Variable & \multicolumn{3}{c}{ Business Model } \\
\cline { 2 - 4 } & $\boldsymbol{\beta}$ & t-value & p-value \\
\hline Product Innovation & 0.452 & 2.768 & 0.021 \\
\hline Process Innovation & 0.324 & 2.562 & 0.018 \\
\hline Managerial Innovation & 0.301 & 2.462 & 0.014 \\
\hline $\mathrm{R}^{2}$ & & 0.765 & \\
\hline Adjusted $\mathrm{R}^{2}$ & 0.744 \\
\hline Sig. $\mathrm{F}$ & 35.664 \\
\hline
\end{tabular}

Results showed that product innovations gave the highest positive significant effect on business model compared to other dimensions of the innovation strategy. It meant that in Batik SMEs, product innovation was the most important factor and could be implemented in form of innovation on the product and its attributes, quality of the materials, and the use of natural dyes. These findings supported a study [8],[9] stating that there was a positive effect of product innovation on business model in SMEs. A study also explained the importance of innovation strategy to improve the business model in SMEs [7]. These findings could also enrich the research literature related to the business model of SMEs. The strategy of product innovation, as measured by the ability to 
improve the novelty of the product compared to its competitors, to improve the quality of the new products produced, and the speed in the development of new products in comparison with other competitors, was the most important dimension as the reflection of innovation strategy in SMEs.

Some previous studies were only limited to the reseach about the SMEs' business model, so that the results of this study provided a model configuration of the strategy of innovation in SMEs with the business model. Results of the study also showed that the innovation strategy could emerge if it was based on the characteristics of entrepreneurs who had the attitude to always be the first to outperform its competitors. It would trigger innovation and ultimately improved the business model of Batik SMEs in East Java that a good innovation strategy would improve innovation in SMEs, which eventually improve the business model on SMEs.

\section{CONCLUSION}

According to previous explanation, it can be concluded that the innovation strategy with product innovation dimension has direct and positive significant effect on the business model of SMEs. Therefore, the SMEs should focus its attention to the factors of product innovation on its innovation strategy to improve the business model practices. Findings of the study could also be considered as the basis for the decision makers to develop SMEs in the future, especially in Indonesia. It is to support the benefit of the implementation of SMEs' business model which is also to provide insights to SMEs on how important the development of business models to improve business performance.

\section{REFERENCES}

[1] Terziovski, M., 2010. "Innovation practice and its performance implications in small and medium enterprises (SMEs) in the manufacturing sector: a resource-based view', Strategic Management Journal, Vol. 31 No. 8, pp. 892-900,

[2] Garcia, R., \& Calantone, 2002.. A critical look at technological innovation typology and innovativeness terminology : A literature review. Journal of product innovation management. 19 (2). pp. 110-132.

[3] Drucker, P.F. 1985. Innovation and Entrepreneurship, Harper \& Row, London,.

[4] Magretta J. 2002. Why business models matter. Harvard Bus. Rev., 80(5): 86-92,

[5] Morris M, Schindehutte M, Allen J. 2005. The entrepreneur's business model: toward a unified perspective. (Special Section: The Nonprofit Marketing Landscape). J. Bus.Res., 58(6): 726-735,.

[6] Sekaran U. 2003. Research methods for business: A skill-building approach (4th ed.). New York: John Wiley \& Sons, Inc.

[7] Hair, Joseph F., Bill Black, Barry Babin, Rolph E. Anderson, and Ronald L Tatham, 2010. Multivariate Data Analysis, Upper Saddle River: Pearson Education, New York.

[8] Amit R, Zott. Value creation in E-business. Strategic Manage. J., 22(67): 493-520, 2001.

[9] Zott C, Amit R. 2007. .Business model design and the performance of entrepreneurial firms. Organ. Sci., 18(2): 181-199. 